This PDF is a simplified version of the original article published in Internet Archaeology. Enlarged images, and interactive features which support this publication can be found in the original version online. All links also go to the online version.

\title{
Archaeology and the History of the Lithuanian Resistance in the 19th and 20th Centuries: in search of the public benefit
}

\author{
Ričardas Dediala
}

\section{Summary}

Two chance discoveries during development-led archaeology in Vilnius have brought the recent history of the Lithuanian Republic to the forefront. The burials of 20 individuals involved in the uprising against the Russian Empire in 1863-1864 were found on Gedimas Hill in 2017, and in 2018 the remains of Adolfas Ramanauskas-Vanagas, a leader of the guerrilla warfare against the Soviet Union in 1944-1953 were found. These discoveries brought great public interest, and advanced knowledge of archaeology. Notably they also encouraged senior politicians from Poland, Belarus and Lithuania to enter into debates on matters that have historically been difficult to discuss.

\section{Introduction}

The uprising against the Russian Empire in 1863-1864 and the guerrilla warfare against the Soviet Union in 1944-1953 are probably the most outstanding episodes within the narrative of the Lithuanian 19th-20th century resistance and struggle for freedom. The years 2017 and 2018 were of great significance for these two historical episodes. It was known that 21 participants in the uprising against the Russian Empire had been executed at Lukiškès Square in Vilnius in 1863-1864. On 3 January 2017, when reinforcement groundworks of the slopes of Gediminas Hill were taking place (Figure 1), several burials thought to be those executed participants were accidentally discovered. After their identification was confirmed, the research continued and a total of 20 burials were unearthed. Only the burial of Revd Stanislovas Išora has yet to be found. 


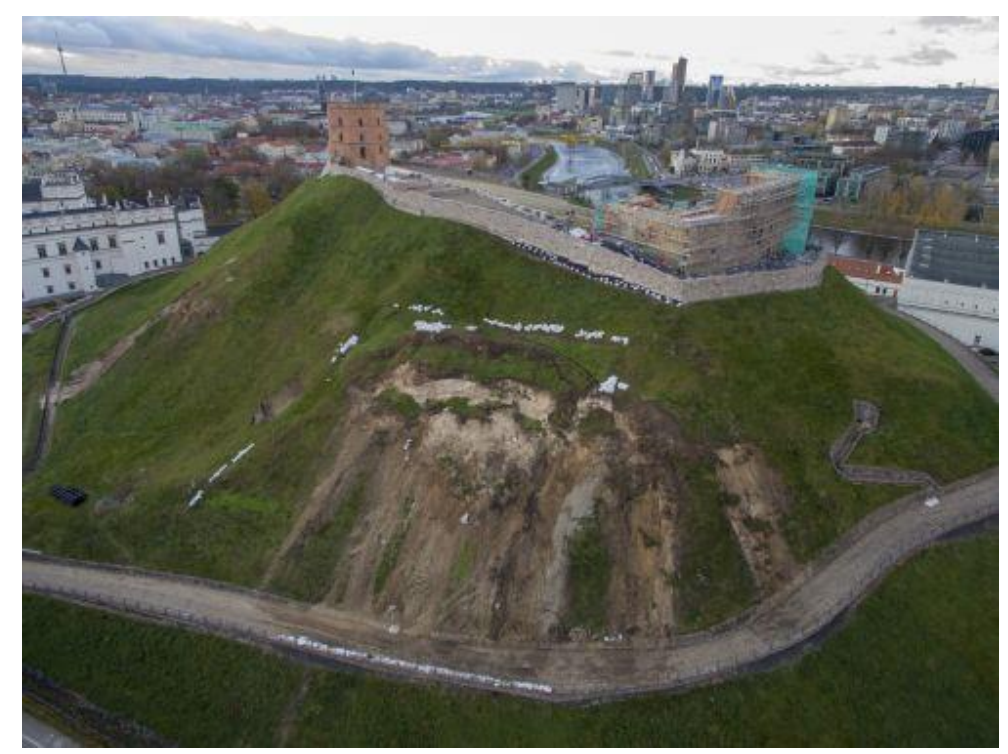

Figure 1: Gediminass Castle Hill slopes (photo by Gytis Grižas)

Meanwhile, in 2018, the remains of Adolfas Ramanauskas-Vanagas, one of the most prominent fighters and a symbol of the Lithuanian anti-Soviet resistance were also discovered. A. Ramanauskas-Vanagas was a teacher who joined the guerrilla warfare after the Soviets had occupied Lithuania and became one of the most outstanding commanders of the partisans (Figure 2). He was arrested in 1956, brutally tortured and shot on 29 November 1957 in Vilnius. Even his killing was not typical, with the executioner standing in front of him and shooting him into his left jawbone. He was then buried in the so-called Vilnius Orphan Cemetery where political prisoners were also interred, as we know today. 


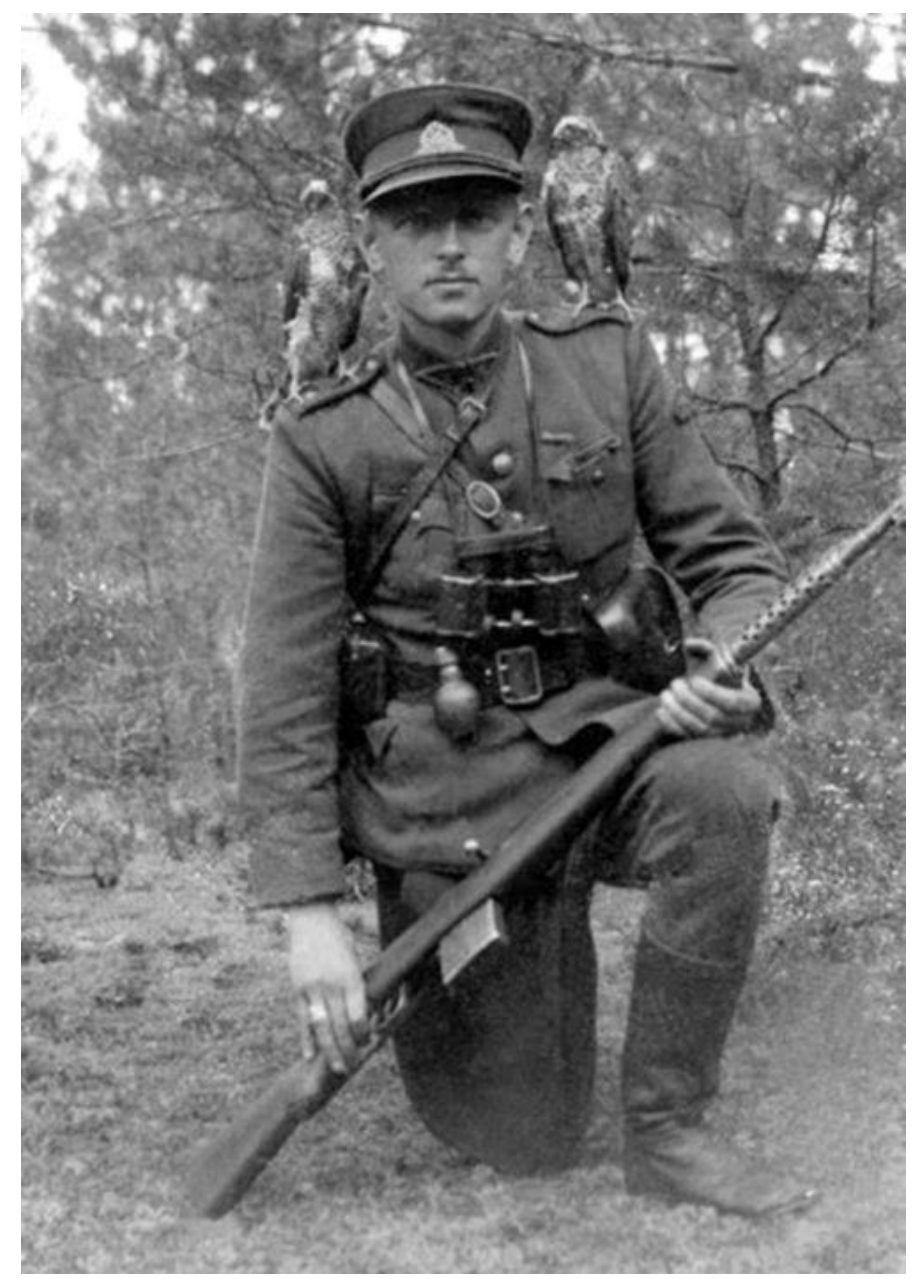

Figure 2: Adolfus Ramanauskas-Vanagas

These two 21st-century discoveries, both closely related to epochs studied by every child during history lessons, wouldn't have happened without the commitment of professional archaeologists. As in the rest of Europe, modern Lithuanian archaeology is strongly involved in commercial research, usually related to construction works, and most of the discoveries are minor and of little interest to the public. The majority of the public perceives archaeology as a matter of 'pure science', bringing few public benefits. Of course this is also related to an overall decline in the value placed on the humanities; investment focuses on capital, money, and profit, forgetting that strong societies are those that feature high levels of cultural development, which is impossible without a strong awareness of the humanities. No doubt, both the Uprising of 1863-1864 and the post-war guerrilla warfare are among the most important episodes in the history of the modern Lithuanian Republic: the great narratives as historians tend to call them, meaning the dominant socio-political historical narratives that both the Tsarist and the Communist regimes tried to erase. It's no coincidence that the participants in the Uprising were buried on the Gediminas Hill - one of the best-fortified sites in Vilnius, which has also always been one of its outstanding landmarks and symbols. After the Russian Empire occupied and divided the Grand Duchy of Lithuania, there was no public access to the Gediminas Hill after 1794: a Russian artillery squad was deployed there and, after the Uprising of 1831, under the order of Emperor Nicholas I, the Gediminas Hill along with the so-called Hill Park was transformed into a fortress. Public access to this area was blocked until the 1890s, when the Gediminas Tower was adapted to accommodate the optical telegraph station. As the public still had no access to the site it 
was deemed suitable to bury the participants in the Uprising, based on the belief that noone would be able to gain access to the graves and turn them into a site of public worship and commemoration. There were almost no sources indicating that the participants in the Uprising were buried there. Partisan A. Ramanauskas-Vanagas was also buried in the cemetery, which was used to bury stillborn children, homeless people, beggars, orphans, suicide victims, psychiatric patients, convicts and prisoners sentenced to death. This was considered to be the perfect site to hide the grave of the most prominent leader of the anti-Soviet Resistance and also prevent it from becoming a site of worship.

\section{Public Interest}

Discoveries of these two burial sites became a sensation not only within the scientific community but also with the public. They raised public interest not only in the historical events but also in the archaeological science itself, as archaeologists had enabled these discoveries in collaboration with the historians.

Numerous interviews in mass media, publications in the press, public debates and newly published books boosted interest in archaeology and made the historians and, more importantly, the public to rethink the said events which - especially the Uprising of 1863-1864 - had been out of the public discourse for some time. These two archaeological discoveries, which would have been impossible without the joint effort of historians, archaeologists, and anthropologists, brought us to an unexpected outcome when even politicians began to talk about the issue of insufficient financing of the scientific centres and that fundamental discoveries wouldn't be possible without proper support from the state.

Another unexpected outcome of these discoveries was a visit by politicians from neighbouring countries, with joint debates on historical matters that are often difficult to arrange. The reburial of $A$. Ramanausko-Vanagas at the most honourable site of the Vilnius Antakalnis Cemetery in 2018 provided impetus for debate not only for the Lithuanian public but also for other countries previously occupied by the Soviet Union. Reburial of the participants of the Uprising of 1863-1864 at the Vilnius Rasos Cemetery turned into an event of national importance for all three states that emerged on the territory of the former Polish-Lithuanian Commonwealth: the ceremony, held in 2019, was attended not only by the President of Lithuania but also by the President of Poland and Deputy Premier of Belarus. Moreover, ordinary citizens of these countries also arrived to pay their respects to the participants of the Uprising in huge numbers and their coffins were jointly carried by Lithuanian and Polish militaries. 


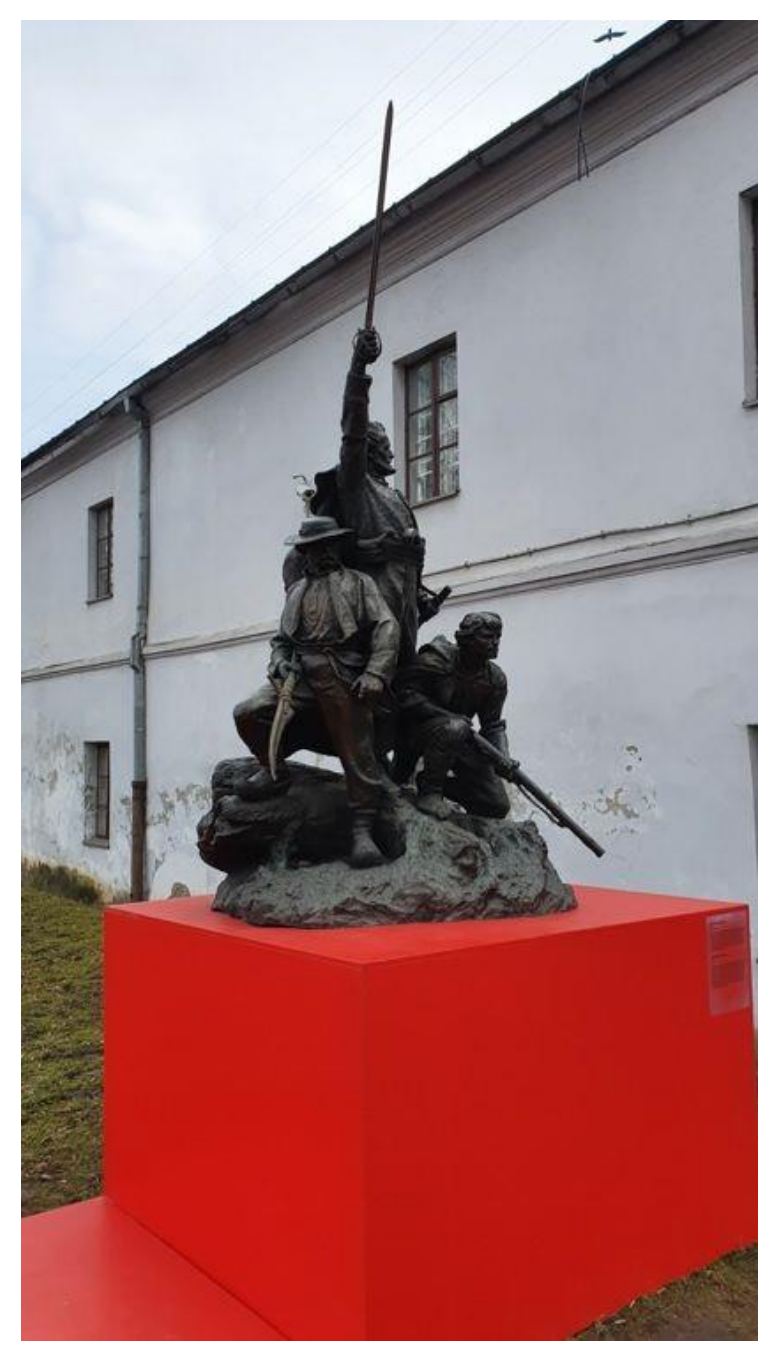

Figure 3: Sculpture Rebels (by Konstantinas Bogdanas) near the exhibition location (photo by Ričardas Dediala)

\section{Public Benefit}

Can we say that these discoveries brought some public benefits? Or was it just a temporary victory for archaeologists and historians? It's hard to say for sure at the moment how these discoveries are going to be perceived in the future; whether just as a curious scientific fact or as something of more importance within the overall historical context. For instance, the exhibition dedicated to the discovery of the remains of the participants of the Uprising (called The Awakened: The History of the Rebels Found on Gedimino Hill), arranged at the site of a derelict guardhouse, was attended by as many as 4000 visitors in the first two days (Figure 3). Public lectures about the Gediminas Hill, the participants in the Uprising, and A. Ramanauskas-Vanagas held at the Lithuanian National Museum and the Palace of the Grand Dukes of Lithuania (eight lectures in total) also enjoyed a great level of interest.

New scientific publications enabled rethinking of the related events for both the scholars and the readers. It looks like the public became more interested in the 19th-century history owing to this episode: earlier the Uprising of 1863-1864 had been researched 
intensively but it had never received so much attention from the general public, as the period of the 19th century fell out of public focus in Lithuania. There are many reasons for this but Lithuanian-Polish political relations were rather cool for a long time and the discoveries allowed the leaders of our countries to remember episodes of our common history and discuss difficult issues. The discovery and reburial of the remains of $A$.

Ramanauskas-Vanagas also gave a new impetus for debates and research on the antiSoviet Resistance; the Government has even allocated funds to search for the burial of another legendary Lithuanian partisan, Juozas Lukša-Daumantas (for both historic and archaeological research). Therefore, at least in the short-term, the archaeological research has come into public focus.

These two discoveries, especially the discovery of the participants in the Uprising, have not only boosted interest in the relevant events of the 19th and 20th centuries but also in the very science of archaeology, which proved to be able to push forwards the boundaries of the historical narrative. Traditionally, the historical narrative was carried out by historians; however, the recent Lithuanian cases have shown that archaeologists, whose meticulous work and cooperation with other scientists not only renewed and fuelled a state-level historical debate but also elevated the value and importance of the very science of archaeology in the eyes of the public, are contributing to the formation of new historical narratives too. This is the greatest victory of all.

\section{Bibliography}

Council of Europe 1992 European Convention on the Protection of the Archaeological Heritage (Revised), Valletta, 16 January 1992. Council of Europe Treaty Series 143. https://www.coe.int/en/web/conventions/full-list//conventions/rms/090000168007bd25 